\title{
Adrenergic Receptors and the Secretion of Glucagon and Insulin from the Isolated, Perfused Canine Pancreas
}

\author{
JOHAN IVERSEN \\ From the Second University Clinic of Internal Medicine, \\ Kommunehospitalet, Aarhus, Denmark
}

A B S T R A C T During perfusion with a glucose concentration of $150 \mathrm{mg} / 100 \mathrm{ml}$, infusions of L-epinephrine, $\mathrm{L}$-norepinephrine, and $\mathrm{D}$-L-isoproterenol at physiological concentrations of $2 \mathrm{ng} / \mathrm{ml}$ for 9 min stimulated secretion of glucagon in a monophasic response pattern, in contrast to the biphasic response normally encountered after glucagon releasing stimuli as previously reported from our laboratory (1971. J. Clin. Invest. $50: 2123$ ). Glucagon was stimulated in spite of a glucose concentration which in itself effectively inhibits glucagon release. Release of insulin was strongly inhibited after epinephrine and norepinephrine, and strongly stimulated after isoproterenol.

During perfusion with a glucose concentration of 25 $\mathrm{mg} / 100 \mathrm{ml}$, secretion of glucagon was greatly accentuated by the catechols investigated. Secretion of insulin remained unchanged after epinephrine and norepinephrine, but was stimulated by isoproterenol.

The catechol induced glucagon release was suppressed or abolished when the beta-blocking agent propanolol was simultaneously infused at a concentration of $1 \mu \mathrm{M}$, while the inhibition of insulin became further accentuated.

The catechol induced glucagon release remained unchanged when alpha blockade was performed using either phentolamine $(1 \mu \mathrm{M})$ or dibenzyline $(10 \mu \mathrm{g} / \mathrm{ml})$, while the inhibition of insulin was converted to a stimulation.

Evidence is thus presented that both the alpha cells and the bet cells are under the influence of adrenergic substances, the stimulation of glucagon release being mediated through a beta receptor and the inhibition of

This work was presented in part at the Seminar on Fenfluramin and Obesity, Nassau, Bahamas, February 1971 and at the Annual Meeting of the European Association for the Study of Diabetes, Southampton, England, September 1971.

Received for publication 11 May 1972 and in revised form 13 April 1973. insulin release being mediated through an alpha receptor.

\section{INTRODUCTION}

Infusions of epinephrine (1) and norepinephrine (2) will inhibit release of insulin in man. This inhibition of insulin release has also been demonstrated in studies on pancreatic slices (3), in isolated islets (4), and recently in the isolated perfused rat pancreas (5). The use of specific alpha and beta receptor blockers have clearly indicated that the inhibition of insulin release is an alpha receptor effect while stimulation of insulin release by adrenergic substances is mediated through beta receptors $(6,7)$.

Thus far it is not known whether secretion of pancreatic glucagon is influenced by adrenergic substances and whether the alpha cells of the islets of Langerhans possess adrenergic receptors as has been shown for the beta cells. The purpose of the present study was to investigate the effect of epinephrine, norepinephrine, and isoproterenol upon the secretion of glucagon and insulin in the isolated perfused canine pancreas and by use of specific receptor blocking compounds to elucidate the receptors responsible.

\section{METHODS}

Fasting male mongrels weighing $20-30 \mathrm{~kg}$ were anesthetized with thiopentone, intubated, and ventilated with positive pressure respiration, using $\mathrm{O}_{2}$ and $N O$ in ratio of $1: 3$.

The operative procedure was carried out and the perfusion system established as described in detail in a previous publication (8). The preparation consisted of the pancreas and the proximal $10 \mathrm{~cm}$ of the attached duodenum. The celiac artery and the portal vein were catheterized. In instances where the anastomosis between the body and the tail of the pancreas is poorly developed the splenic artery was also retrogradely cannulated. The pancreas was perfused without recirculation with a synthetic medium consisting of a Krebs-Ringer buffer was modified to the 
electrolyte concentrations found in dog plasma and contained 4\% dextran (Macrodex Mw 70.000, Pharmacia, Uppsala, Sweden), $0.2 \%$ bovine albumin (Ortho Pharmaceutical Corp., Raritan, N. J., and fumarate, pyruvate, and glutamate each at a concentration of $5 \mathrm{mM}$. Glucose concentration of the perfusate was $25 \mathrm{mg} / 100 \mathrm{ml}$. The perfusate was equilibrated by a roller screen oxygenator in an atmosphere of $94.4 \% \mathrm{O}_{2}$ and $5.6 \% \quad \mathrm{CO}_{2}$ and was heated to a temperature of $37 \pm 1^{\circ} \mathrm{C}$ by use of low wattage heaters with a large surface area. The perfusate was pumped through the gland by means of a roller pump. A constant flow rate of $18-20 \mathrm{ml} / \mathrm{min}$ was achieved with a perfusion pressure which settles between 30 and $40 \mathrm{~mm} \mathrm{Hg}$ within 5-10 minutes after start of the perfusion. Flow and pressure were constant throughout the experiment.

Biochemical methods. Glucagon and insulin were measured by radioimmunoassay using minor modifications of the wick chromatography method described by Ørskov (9, 10). (For details see 11.) In order to decrease the sensitivity limit for exact determinations of the low insulin values obtained during perfusion with a glucose concentration of $25 \mathrm{mg} / 100 \mathrm{ml}$ sample size was increased from $20 \mu \mathrm{l}$ to $85 \mu \mathrm{l}$. $2 \mathrm{~min}$ before and during infusion of the catecholamines and the blocking substances the hormone concentrations were measured in duplicate determinations. The hormone concentrations in the rest of the experiments were measured in single determinations.

In the glucagon assay it is possible to distinguish differences in glucagon concentrations of $10 \mathrm{pg} / \mathrm{ml}$ with $95 \%$ confidence $(0 \mathrm{pg} / \mathrm{ml}$ standards, $\mathrm{N}=6$, vs. $10 \mathrm{pg} / \mathrm{ml}$ standards, $n=3$ ). The antiglucagon serum employed does not distinguish between glucagon-like activity from the gut and glucagon from the pancreas. However, the present preparation consists of the pancreas and only the proximal $10 \mathrm{~cm}$ of the attached duodenum which contains very little or no glucagon-like immunoreactivity (12-14).

No proteolytic enzymes escaped from the perfused pancreas. This was apparent from the fact that incubation damage to hormones in the perfusate was identical to that calculated from the standard media both as estimated chromatographically by the nonspecific migration of labeled hormone with plasma proteins and immunologically as the maximum binding of labeled hormone in the presence of an antibody excess.

Glucose was measured using a glucose oxidase method (Glox, Kabi Reagents, Stockholm, Sweden). There was no interference from the high dextran concentrations.

Experimental procedure. Samples were taken every minuate from the influx and the efflux. Influx samples were checked at intervals for the correct glucose concentration. To protect glucagon against degradation $250 \mu 1$ EDTA (30\%) was added to the tubes collecting the efflux, resulting in a final concentration of $4 \mathrm{mg} / \mathrm{ml}$. The samples were transferred within a half hour to a freezer providing a temperature of $-20^{\circ} \mathrm{C}$.

The substances to be examined were added to the perfusate by means of constant infusion syringes, containing appropriate high concentrations. The infusion pumps were adjusted to speeds which added $0.1-0.25 \mathrm{ml} / \mathrm{min}$ to the overall flow which was $18-20 \mathrm{ml} / \mathrm{min}$. When any of the substances was administered it was dissolved immediately before use in purified distilled water adjusted to a $\mathrm{pH}$ of 3.5.

L-epinephrine and L-norepinephrine (Sigma Chemical Co., St. Louis, Mo.), isoproterenol (obtained as DL-N-isopropylarterenol), propanolol (Inderal, Ayerst Laboratories,
New York), phentolamine (Regitine, Ciba Pharmaceutical Co., Summit. N. J.) and dibenzyline (obtained as phenoxybenzamine $\mathrm{HCl}$ ) were commercially available. The standard curves for glucagon and insulin were not effected by the adrenergic substances or the receptor blocking compounds.

The pancreas was perfused for an equilibration period of 20-30 min with a glucose concentration of $25 \mathrm{mg} / 100 \mathrm{ml}$. The glucagon and insulin response to glucose concentrations of 25,150 , and $350 \mathrm{mg} / 100 \mathrm{ml}$ was investigated. The effect of adrenergic substances was investigated at glucose concentrations of $25 \mathrm{mg} / 100 \mathrm{ml}$ and $150 \mathrm{mg} / 100 \mathrm{ml}$ in the perfusate.

Two different experimental set ups were chosen for investigating the effect of adrenergic substances. In the first (type I experiment) the effect of several agents was tested in the same pancreas. Although it was found that the effect of the different catecholamines was of a short duration, lasting only until termination of the infusion, care was taken to reverse the order of stimulations in the different experiments to ensure that the response seen after one stimulus was not influenced by the previous one. The effect of the receptor blockers, propanolol and phentolamine, was investigated by comparing the effect of the catecholamine alone with the effect of a simultaneous infusion of the blocker and the same catecholamine.

When one of the receptor blocking compounds had been infused, subsequent testing of the pancreas always consisted of a simultaneous infusion of the same receptor blocker and an adrenergic substance, as preliminary experiments had shown that stimulation subsequent to infusion of blockers was influenced by the continued effect of the blocker. This suggested that elimination of these compounds from the tissue was slow. For the same reason the effects of an alpha receptor blocker and a beta receptor blocker were never investigated in the same perfusion experiment.

In the second experimental procedure (type II exper1ment) the effect of only one catecholamine was investigated in each experiment. The blocker was either infused over a period of $10 \mathrm{~min}$ prior to the catecholamine infusion or the catecholamine infusion-preceded that of the blocker by $10-15 \mathrm{~min}$. The results from these two experimental sereis (type I and type II experiments) were comparable.

At the end of each experiment the insulin response to a glucose concentration of $350 \mathrm{mg} / \mathrm{ml}$ was checked in order to prove that the beta cells were still capable of the characteristic biphasic insulin response.

\section{RESULTS}

\section{Effect of epinephrine, norepinephrine, and isoproterenol during perfusion with glucose concentrations of 25 and $150 \mathrm{mg} / 100 \mathrm{ml}$ (type I experiments)}

Stimulation of glucagon secretion was obtained in all of 23 perfusion experiments with an infusion of epinephrine $(2 \mathrm{ng} / \mathrm{ml}$ for $9 \mathrm{~min}$ ), in each of 8 perfusion experiments with an infusion of norepinephrine (2 $\mathrm{ng} / \mathrm{ml}$ for $9 \mathrm{~min}$ ) and in each of 11 perfusion experiments with an infusion of isoproterenol $(2 \mathrm{ng} / \mathrm{ml}$ for $9 \mathrm{~min}$ ).

The different pancreatic preparations under the same standardized conditions showed a variability in their 
TABLE I

Effect of Propanolol and Phentolamine on Epinephrine-

\begin{tabular}{|c|c|c|c|c|c|c|}
\hline \multirow{2}{*}{$\begin{array}{c}\text { Adrenergic } \\
\text { subst. } \pm \text { blocker }\end{array}$} & \multirow{2}{*}{\multicolumn{2}{|c|}{$\begin{array}{c}\text { Glucose } \\
\text { conc. } 8\end{array}$}} & \multirow{2}{*}{$\begin{array}{l}\text { Prestimulation } \| \\
(\text { mean } \pm \text { SEM) }\end{array}$} & \multicolumn{3}{|c|}{ Concentrations during stimulation } \\
\hline & & & & Time $(\min ): 1$ & 2 & 3 \\
\hline \multirow{4}{*}{$\begin{array}{l}\text { Epinephrine } \\
- \text { blocker }\end{array}$} & 150 & PG & 98.7 中11.3 (18)** & $124.2 \pm 14.8$ & $184.9 \pm 14.7$ & $223.0 \pm 16.8$ \\
\hline & & I & $303.0 \pm 32.1(18)$ & $396.6 \pm 52.1$ & $788.5 \pm 155.0$ & $213.3 \pm 34.5$ \\
\hline & 25 & PG & $287.5 \pm 39.0$ & $308.1 \pm 45.9$ & $402.1 \pm 64.0$ & $431.6 \pm 48.1$ \\
\hline & & I & $20.4 \pm 3.5$ & $14.8 \pm 2.3$ & $15.3 \pm 2.7$ & $16.5 \pm 2.7$ \\
\hline \multirow{4}{*}{$\begin{array}{l}\text { Epinephrine } \\
\quad+\text { propanolol }\end{array}$} & 150 & PG & $132.9 \pm 34.0$ & $140.8 \pm 34.2$ & $146.7 \pm 38.6$ & $156.7 \pm 41.6$ \\
\hline & & I & $293.1 \pm 48.9(10)$ & $283.9 \pm 46.6$ & $175.5 \pm 27.3$ & $108.6 \pm 18.2$ \\
\hline & 25 & PG & $363.6 \pm 91.6$ & $369.2 \pm 95.9$ & $282.0 \pm 103.2$ & $353.7 \pm 101.8$ \\
\hline & & I & $20.7 \pm 8.0$ & $16.2 \pm 5.8$ & $12.0 \pm 4.4$ & $12.0 \pm 3.4$ \\
\hline \multirow{4}{*}{$\begin{array}{l}\text { Epinephrine } \\
\quad+\text { phentolamine }\end{array}$} & 150 & PG & $174.2 \pm 64.4$ & $166.6 \pm 78.9$ & $215.0 \pm 60.5$ & $297.4 \pm 80.9$ \\
\hline & & I & $398.0 \pm 148.4(5)$ & $1,614.2 \pm 616.3$ & $2,778.2 \pm 661.0$ & $1,642.0 \pm 394.0$ \\
\hline & 25 & PG\$8 & 265.0 & 281.5 & 321.0 & 479.0 \\
\hline & & 188 & 10.1 & 8.5 & 10.5 & 9.5 \\
\hline
\end{tabular}

* Pancreatic glucagon, $\mathrm{pg} / \mathrm{ml}$.

$\ddagger$ Insulin, $\mu \mathrm{U} / \mathrm{ml}$.

\& Glucose concentration in the perfusate, $\mathrm{mg} / 100 \mathrm{ml}$.

II The prestimulation period is defined as the 10-15 min preceding infusion of the stimulatory substance. The prestimulation value in each experiment is the mean of about 10 samples.

I Mean concentration ( $\pm \mathrm{SEM}$ ) of the last $8 \mathrm{~min}$ of the infusion.

** Number of experiments.

$\ddagger$ Mean concentration $( \pm \mathrm{SEM})$ of the last $6 \mathrm{~min}$ of the infusion.

$\$ \$$ Mean values given.

responses to the catecholamine infusions which was significantly correlated to the glucagon output in the control state with a $P$ value $<0.05$. All of the data during catecholamine infusions were therefore converted to percentage of control. The mean percent findings are shown in Figs. 1-3, and the mean concentra- tions obtained during the stimulations are recorded in Tables I-IV. The data were pooled from type I experiments where one or several catecholamines and a receptor blocker were tested in the same experiment.

The glucagon response to catechols was monophasic in contrast to the characteristic biphasic response pat-

TABLE II Effect of Propanolol and Phentolamine on Norepinephrine-

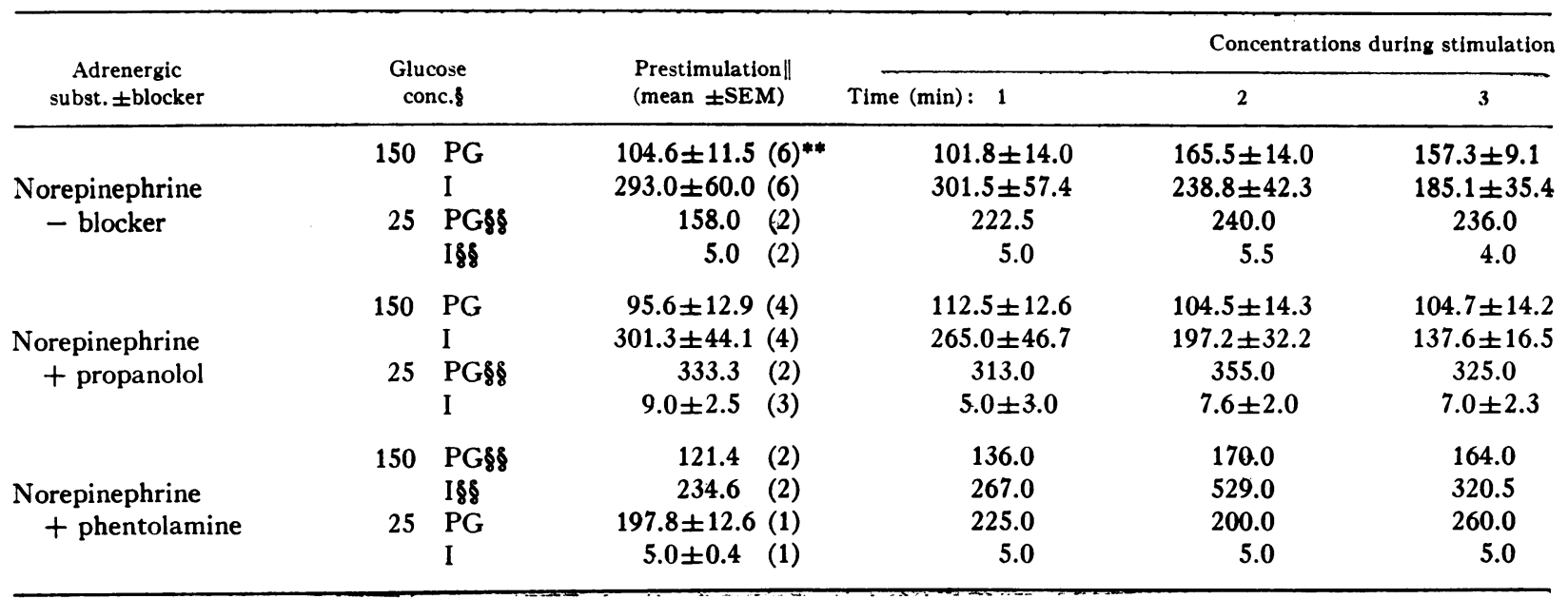

See footnotes Table I. 
Induced Changes on the Secretion of $P G^{*}$ and If

\begin{tabular}{|c|c|c|c|c|c|c|}
\hline \multicolumn{6}{|l|}{ (mean \pm SEM) } & \multirow{2}{*}{$\begin{array}{l}\text { Mean concentration } \\
\text { during stimulation } q \\
(\text { mean } \pm \text { SEM })\end{array}$} \\
\hline 4 & 5 & 6 & 7 & 8 & 9 & \\
\hline $219.3 \pm 18.2$ & $237.0 \pm 18.5$ & $238.1 \pm 19.7$ & $245.0 \pm 20.8$ & $251.8 \pm 22.2$ & $243.4 \pm 24.3$ & $229.7 \pm 17.1$ \\
\hline $111.5 \pm 14.6$ & $104.6 \pm 14.6$ & $106.6 \pm 14.1$ & $106.3 \pm 15.7$ & $120.8 \pm 17.8$ & $115.0 \pm 18.6$ & $110.5 \pm 14.9 \ddagger \ddagger$ \\
\hline $515.6 \pm 73.4$ & $497.7 \pm 66.9$ & $445.6 \pm 57.2$ & $476.2 \pm 79.2$ & $512.0 \pm 92.1$ & $453.7 \pm 58.6$ & $466.8 \pm 63.8$ \\
\hline $9.7 \pm 2.0$ & $14.4 \pm 2.7$ & $13.2 \pm 2.0$ & $9.5 \pm 1.9$ & $12.4 \pm 2.7$ & $14.6 \pm 4.0$ & $14.6 \pm 2.4$ \\
\hline $155.2 \pm 35.6$ & $152.5 \pm 36.0$ & $148.3 \pm 34.4$ & $138.5 \pm 35.6$ & $151.1 \pm 37.4$ & $141.0 \pm 34.6$ & $148.7 \pm 36.3$ \\
\hline $96.2 \pm 20.1$ & $98.8 \pm 20.5$ & $102.3 \pm 17.7$ & $87.8 \pm 14.8$ & $97.5 \pm 20.6$ & $92.2 \pm 18.8$ & $95.6 \pm 18.2 \ddagger \ddagger$ \\
\hline $396.2 \pm 86.1$ & $357.2 \pm 92.4$ & $366.3 \pm 145.1$ & $366.6 \pm 169.8$ & $368.2 \pm 106.1$ & $369.0 \pm 121.0$ & $364.9 \pm 103.8$ \\
\hline $11.6 \pm 5.7$ & $13.2 \pm 4.0$ & $12.0 \pm 3.2$ & $14.5 \pm 5.2$ & $10.3 \pm 4.3$ & $12.0 \pm 3.4$ & $12.5 \pm 3.6$ \\
\hline $311.0 \pm 80.2$ & $309.8 \pm 78.7$ & $327.2 \pm 91.8$ & $348.4 \pm 101.6$ & $321.4 \pm 100.4$ & $345.0 \pm 90.0$ & $309.3 \pm 83.8$ \\
\hline $1,501.4 \pm 390.1$ & $1,641.6 \pm 379.4$ & $1,649.2 \pm 260.8$ & $1,801.4 \pm 346.2$ & $1,959.4 \pm 409.4$ & $1,789.5 \pm 311.5$ & $1,696.0 \pm 318.9 \ddagger \ddagger$ \\
\hline 448.5 & 472.5 & 480.5 & 534.5 & 526.0 & 397.5 & 507.4 \\
\hline 8.5 & 10.5 & 9.0 & 9.5 & 11.5 & 11.0 & 9.9 \\
\hline
\end{tabular}

tern previously reported following gastrin, pancreozymin, and arginine stimulation (11). Glucagon rose within 1 or $2 \mathrm{~min}$ to a plateau which was almost constant until termination of the infusion upon which the glucagon concentration gradually leveled off to the prestimulation value.
The stimulatory effect of the adrenergic substances was studied at low glucose concentrations as well as at the high concentration of glucose of $150 \mathrm{mg} / 100 \mathrm{ml}$, which effectively inhibits basal glucagon secretion in our experiments. At the low glucose concentrations of $25 \mathrm{mg} / 100 \mathrm{ml}$ epinephrine and norepinephrine stimu-

Induced Changes on the Secretion of $P G^{*}$ and If

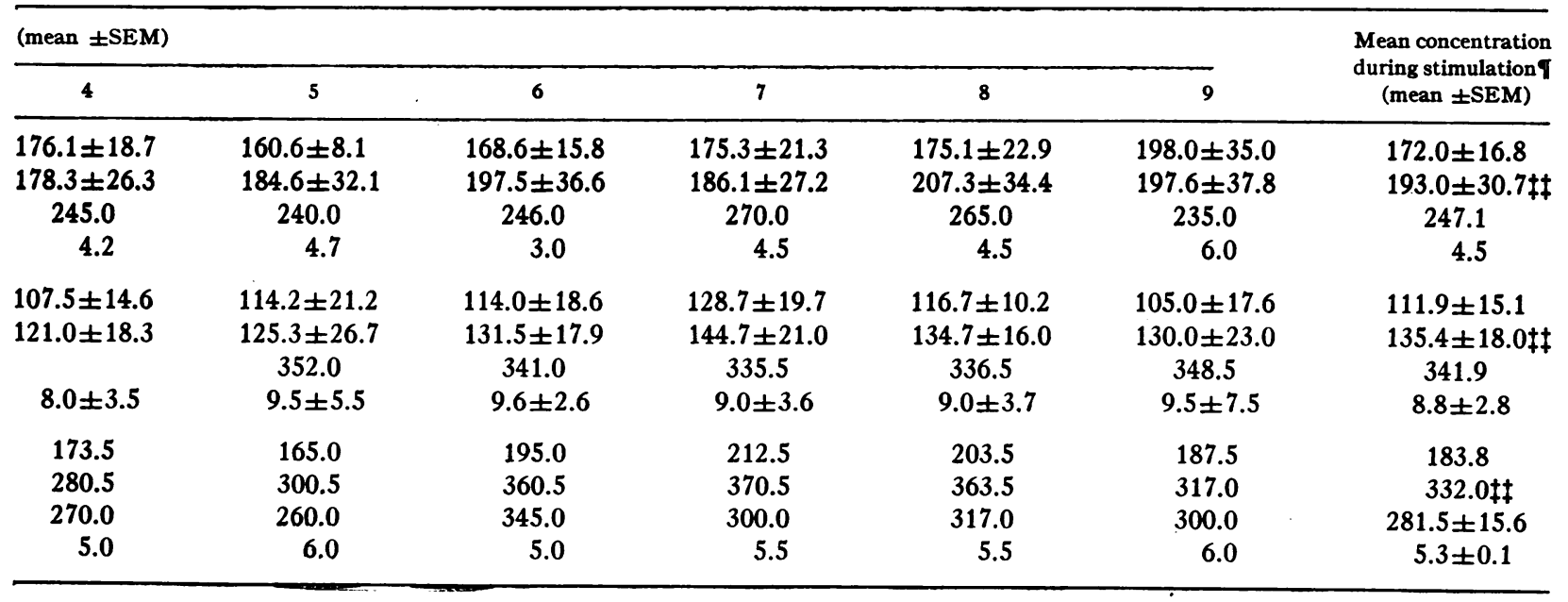


TABLE III

Effect of Propanolol and Phentolamine on Isoproterenol-

\begin{tabular}{|c|c|c|c|c|c|c|}
\hline \multirow{2}{*}{$\begin{array}{c}\text { Adrenergic } \\
\text { subst. } \pm \text { blocker }\end{array}$} & \multirow{2}{*}{\multicolumn{2}{|c|}{$\begin{array}{l}\text { Glucose } \\
\text { conc. } \S\end{array}$}} & \multirow{2}{*}{$\begin{array}{l}\text { Prestimulation } \| \\
(\text { mean } \pm \text { SEM })\end{array}$} & \multicolumn{3}{|c|}{ Concentrations during stimulation } \\
\hline & & & & Time $(\min ): 1$ & 2 & 3 \\
\hline \multirow{4}{*}{$\begin{array}{l}\text { Isoproterenol } \\
\text { - blocker }\end{array}$} & 150 & PG & $113.6 \pm 13.8(7)^{* *}$ & $115.4 \pm 21.2$ & $166.5 \pm 24.8$ & $188.1 \pm 20.6$ \\
\hline & & I & $328.2 \pm 77.5(6)$ & $2,376.5 \pm 513.8$ & $5,702.6 \pm 656.6$ & $2,790.0 \pm 473.5$ \\
\hline & 25 & PG & $204.0 \pm 58.6(4)$ & $227.0 \pm 61.3$ & $524.0 \pm 213.7$ & $378.7 \pm 105.4$ \\
\hline & & $\mathrm{I}$ & $7.3 \pm 2.6$ & $8.2 \pm 3.3$ & $22.8 \pm 6.4$ & $17.4 \pm 4.7$ \\
\hline \multirow{4}{*}{$\begin{array}{l}\text { Isoproterenol } \\
\quad+\text { propanolol }\end{array}$} & 150 & PG & $132.0 \pm 16.6(4)$ & $147.0 \pm 28.1$ & $205.0 \pm 33.3$ & $185.5 \pm 17.5$ \\
\hline & & $\mathrm{I}$ & $361.0 \pm 97.4(4)$ & $1,899.7 \pm 565.4$ & $907.5 \pm 67.2$ & $522.5 \pm 38.8$ \\
\hline & 25 & PG§§ & $341.7 \quad(2)$ & 335.0 & 353.5 & 321.0 \\
\hline & & I§§ & $8.5 \quad(2)$ & 8.0 & 8.5 & 7.0 \\
\hline \multirow{4}{*}{$\begin{array}{l}\text { Isoproterenol } \\
\quad+\text { phentolamine }\end{array}$} & 150 & PG§§ & $178.6 \quad(2)$ & 186.0 & 347.5 & 391.0 \\
\hline & & $\mathrm{I} \S \S$ & $276.6 \quad(2)$ & $2,212.5$ & $4,816.0$ & $3,359.0$ \\
\hline & 25 & PG§§ & 170.2 & 210.0 & 310.0 & 325.0 \\
\hline & & $I \$ \S$ & $6.7 \quad(2)$ & 6.0 & 15.0 & 14.0 \\
\hline
\end{tabular}

See footnotes Table I.

lated secretion of glucagon almost to the same degree. Following epinephrine the glucagon level increased to a mean percentage value of $66 \%$ above control values ( $\mathrm{SEM} \pm 9, \mathrm{~N}=8$ (Fig. 1) during the infusion, while norepinephrine increased the output to a mean of $53 \%$ $(\mathrm{N}=2)$ (Fig. 2). Isoproterenol was the most effective releaser of glucagon and increased the glucagon to a mean percentage of $122 \%$ ( $\mathrm{SEM} \pm 10, \mathrm{~N}=5$ ) (Fig. 3 ). During perfusion with a glucose concentration of $150 \mathrm{mg} / 100 \mathrm{ml}$ epinephrine increased glucagon to $165 \%$ ( $\mathrm{SEM} \pm 27, \mathrm{~N}=18$ ) (Fig. 1). Norepinephrine increased glucagon to $81 \%(\mathrm{SEM} \pm 38, \mathrm{~N}=6)$ (Fig. 2) and following isoproterenol it rose to $138 \%$ (SEM $\pm 19, \mathrm{~N}=5$ ) (Fig. 3).

While all the catechols investigated stimulated release of glucagon in a uniform way the effect upon insulin release was more heterogeneous. At the high glucose concentration each substance exhibited its own characteristic response pattern. Following isoproterenol infusion the insulin response was biphasic, similar to the characteristic response pattern seen after an increment in glucose, gastrointestinal hormones, and amino acids. The mean insulin level rose to a peak at $2 \mathrm{~min}$ of $2,050 \%$ ( $\mathrm{SEM} \pm 434, \mathrm{~N}=4$ ) leveling off at a mean

TABLE IV Effect of Propanolol, Phentolamine, and

\begin{tabular}{|c|c|c|c|c|c|c|c|}
\hline \multirow[b]{2}{*}{$\begin{array}{l}\text { Adrenergic } \\
\text { blocker }\end{array}$} & \multirow{2}{*}{\multicolumn{2}{|c|}{$\begin{array}{c}\text { Glucose } \\
\text { conc. } \S\end{array}$}} & \multirow{2}{*}{\multicolumn{2}{|c|}{$\begin{array}{l}\text { Prestimulation } \| \\
(\text { mean } \pm \text { SEM) }\end{array}$}} & \multicolumn{3}{|c|}{ Concentrations during stimulation } \\
\hline & & & & & Time $(\min ): 1$ & 2 & 3 \\
\hline \multirow{4}{*}{ Propanolol } & 150 & PG & $136.9 \pm 47.9$ & $(6)^{* *}$ & $94.8 \pm 34.6$ & $143.3 \pm 48.6$ & $142.6 \pm 54.1$ \\
\hline & & I & $280.4 \pm 51.1$ & (8) & $283.7 \pm 56.9$ & $295.3 \pm 58.1$ & $280.6 \pm 43.6$ \\
\hline & 25 & PG & $449.5 \pm 74.3$ & (4) & $440.5 \pm 70.1$ & $488.5 \pm 73.8$ & $452.7 \pm 113.7$ \\
\hline & & I & $17.0 \pm 5.7$ & (4) & $17.7 \pm 6.4$ & $12.7 \pm 3.5$ & $12.2 \pm 2.4$ \\
\hline \multirow{4}{*}{ Phentolamine } & 150 & PG & $175.2 \pm 56.5$ & (4) & $197.7 \pm 64.9$ & $183.5 \pm 67.1$ & $192.5 \pm 60.7$ \\
\hline & & I & $413.8 \pm 133.1$ & (4) & $539.6 \pm 185.0$ & $638.6 \pm 226.8$ & $513.5 \pm 155.4$ \\
\hline & 25 & PG & $262.9 \pm 38.9$ & (3) & $273.3 \pm 54.7$ & $267.0 \pm 25.8$ & $275.0 \pm 51.7$ \\
\hline & & I & $12.0 \pm 4.4$ & (3) & $18.3 \pm 4.7$ & $15.0 \pm 3.2$ & $8.3 \pm 3.1$ \\
\hline \multirow[t]{2}{*}{ Dibenzyline } & 150 & PG & $160.6 \pm 45.1$ & (4) & $174.2 \pm 49.1$ & $164.5 \pm 46.6$ & $175.5 \pm 49.4$ \\
\hline & & I & $332.8 \pm 87.3$ & (4) & $415.0 \pm 73.3$ & $403.0 \pm 119.4$ & $544.6 \pm 161.9$ \\
\hline
\end{tabular}

See footnotes Table I. 
Induced Changes in the Secretion of $P G^{*}$ and If

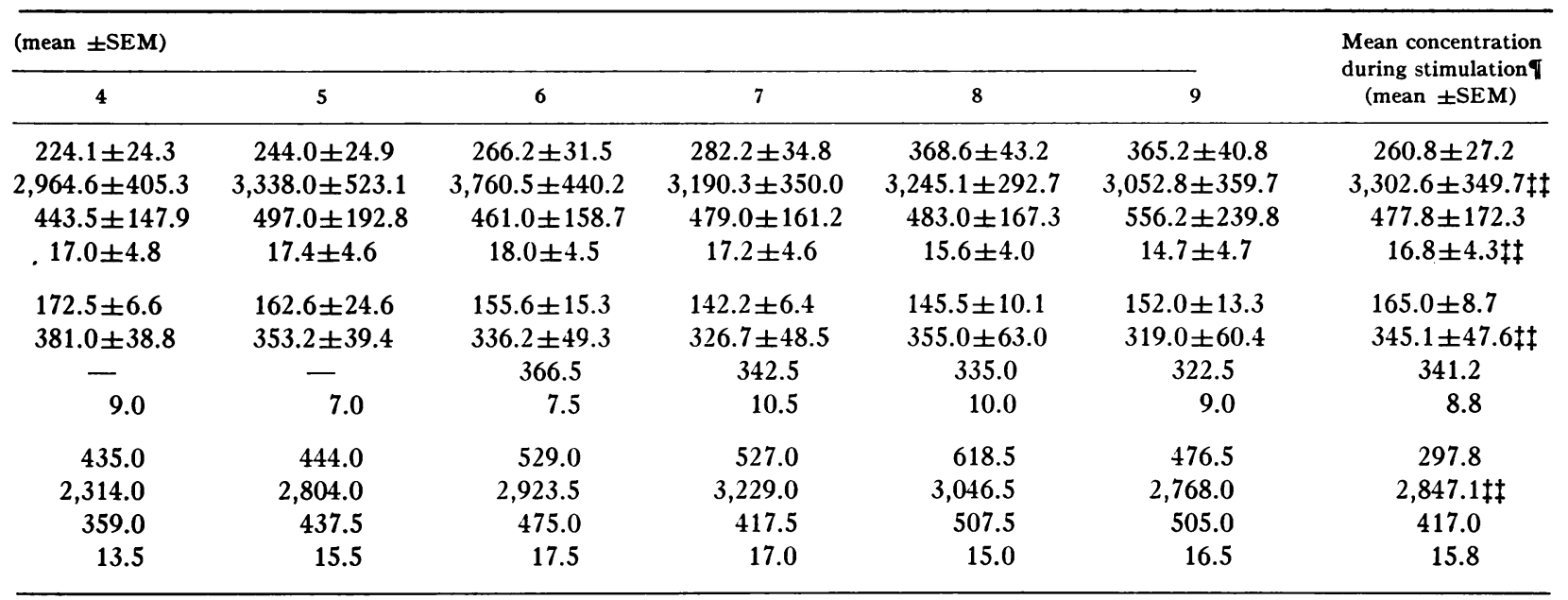

percentage value of $1,498 \%(\mathrm{SEM} \pm 247)$ during the last $6 \mathrm{~min}$ of the infusion (Fig. 3). Infusion of epinephrine effectively inhibited release of insulin. However, the immediate effect observed was a short transient increase in the mean insulin level to a peak at 2 min of $149 \%$ ( $S E M \pm 46, N=18)$. This short-lasting spike in insulin was rapidly followed by a suppression of the release from the 4 th $\mathrm{min}$ of the infusion to a mean percentage value of $-64 \%(\mathrm{SEM} \pm 3)$ during the rest of the infusion (Fig. 2). Finally, at termination of the infusion in most experiments the inhibition was followed by a short release spike before the prestimula- tion value was again reached. Norepinephrine also inhibited insulin release. The mean insulin level decreased to a mean percentage during the last $6 \mathrm{~min}$ of the infusion of $-21 \%(\mathrm{SEM} \pm 8, \mathrm{~N}=6)$. The $2 \mathrm{~min}$ value was $-17 \%$ (SEM \pm 11$)$ (Fig. 2).

At $25 \mathrm{mg} / 100 \mathrm{ml}$ glucose, epinephrine induced a slight decrease in the mean insulin level to a mean percentage during the infusion of $-25 \%$ (SEM $\pm 4, \mathrm{~N}$ $=8$ ) (Fig. 1). No primary stimulation of insulin release was observed at this glucose concentration. Norepinephrine did not influence secretion of insulin (Fig. 2 ), while isoproterenol released insulin in a biphasic

Dibenzyline on Secretion of $P G^{*}$ and I

(mean \pm SEM)

\begin{tabular}{ccccccr}
\hline 4 & 5 & 6 & 7 & 8 & $\begin{array}{c}\text { stimulation } \\
\text { (mean } \pm \text { SEM) }\end{array}$ \\
\hline $154.6 \pm 44.4$ & $150.3 \pm 45.1$ & $120.1 \pm 44.7$ & $156.0 \pm 47.6$ & $134.8 \pm 39.1$ & $143.2 \pm 45.8$ & $134.6 \pm 44.5$ \\
$261.8 \pm 47.3$ & $269.3 \pm 52.0$ & $257.7 \pm 45.8$ & $270.2 \pm 47.4$ & $273.1 \pm 46.1$ & $267.5 \pm 46.5$ & $271.9 \pm 47.1$ \\
$411.7 \pm 69.5$ & $473.7 \pm 103.9$ & $457.5 \pm 93.2$ & $460.0 \pm 99.6$ & $430.7 \pm 88.4$ & $504.3 \pm 128.6$ & $455.0 \pm 91.7$ \\
$12.0 \pm 2.4$ & $15.5 \pm 5.6$ & $10.2 \pm 2.0$ & $13.0 \pm 4.2$ & $11.5 \pm 2.7$ & $15.7 \pm 7.0$ & $12.8 \pm 3.4$ \\
$199.9 \pm 65.5$ & $214.2 \pm 72.6$ & $191.0 \pm 72.9$ & $208.0 \pm 61.0$ & $215.2 \pm 66.4$ & $243.6 \pm 106.9$ & $200.9 \pm 68.6$ \\
$512.2 \pm 172.5$ & $465.0 \pm 143.8$ & $472.7 \pm 148.6$ & $536.0 \pm 181.0$ & $495.7 \pm 154.9$ & $375.6 \pm 106.9$ & $508.1 \pm 161.2$ \\
$288.0 \pm 47.5$ & $296.3 \pm 55.3$ & $286.0 \pm 58.5$ & $261.6 \pm 57.3$ & $257.3 \pm 60.8$ & $277.0 \pm 90.4$ & $275.9 \pm 51.4$ \\
$9.6 \pm 5.2$ & $12.5 \pm 3.4$ & $9.6 \pm 3.1$ & $11.3 \pm 2.8$ & $12.0 \pm 1.5$ & $14.5 \pm 6.4$ & $11.1 \pm 2.7$ \\
$165.7 \pm 50.3$ & $164.5 \pm 48.5$ & $157.5 \pm 51.2$ & $152.0 \pm 49.0$ & $147.0 \pm 45.6$ & $153.7 \pm 50.8$ & $160.0 \pm 48.5$ \\
$524.2 \pm 180.6$ & $456.0 \pm 114.7$ & $444.7 \pm 95.5$ & $445.7 \pm 108.8$ & $388.7 \pm 77.4$ & $410.5 \pm 85.6$ & $438.7 \pm 109.0$ \\
\hline
\end{tabular}




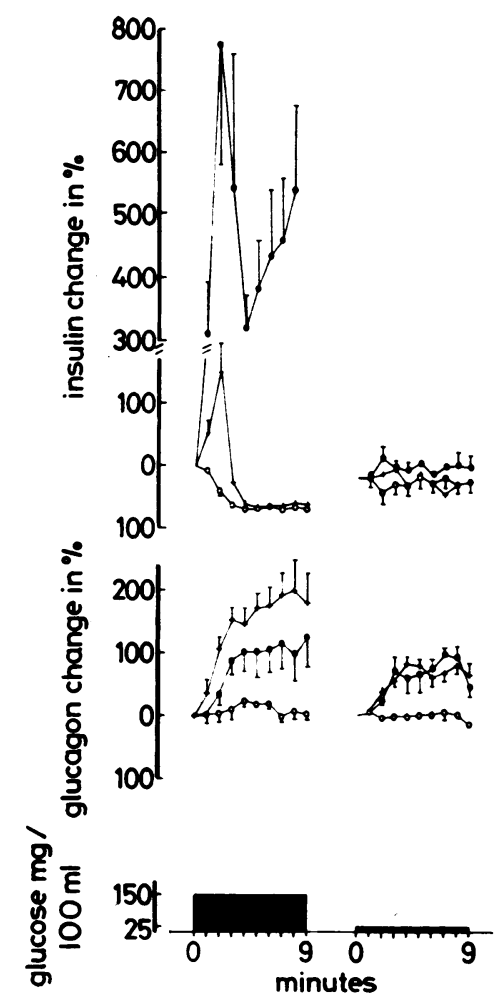

Figcre 1 Effect of epinephrine. Mean percentage change of glucagon and insulin ( \pm SEM) during epinephrine +-+ , epinephrine and propanolol $\bigcirc-\bigcirc$, and epinephrine and phentolamine infusions - -0 in the different perfusion experiments both at a glucose concentration of $150 \mathrm{mg} / 100 \mathrm{ml}$ (left) and at $25 \mathrm{mg} / 100 \mathrm{ml}$ (right). Table I gives the corresponding mean concentrations $( \pm \mathrm{SEM})$ from the same experiments and the number of stimulations.

pattern (Fig. 5). Insulin rose to a peak at $2 \mathrm{~min}$ of $354 \%$ ( $\mathrm{SEM} \pm 176, \mathrm{~N}=5$ ) and leveled off at a plateau of $189 \%$ (SEM \pm 69 ) (Fig. 3 ).

Effect of propanolol, phentolamine, and dibenzyline alone during perfusion with a glucose concentration of 25 and $150 \mathrm{mg} / 100 \mathrm{ml}$ (type I experiments )

Because of chemical similarities between adrenergic substances and the adrenergic blocking compounds and because it has been reported that these substances in certain higher concentrations may influence release of insulin themselves (5), the effect of infusion of propanolol, phentolamine, and dibenzyline were investigated. The substances were infused for $9 \mathrm{~min}$, propanolol and phentolamine at equimolar concentrations of $1 \mu \mathrm{M}$ and dibenzyline at a concentration of $10 \mu \mathrm{g} / \mathrm{ml}$.

Infusion of propanolol was studied in nine perfusion experiments. Glucagon and insulin were not influenced either at low or at high concentrations of glucose. In- fusion of phentolamine was studied in six perfusion experiments. At low glucose concentrations neither glucagon nor insulin were influenced. At high glucose concentrations phentolamine caused a small increase in glucagon to a mean percentage level during the infusion of $14 \%$ (SEMI $\pm 6, N=4$ ). Insulin was also slightly increased by phentolamine, the mean percentage during the infusion being $28 \%(\mathrm{SEM} \pm 10, \mathrm{~N}=4)$. However, the increases in glucagon and insulin were not significant. The effect of dibenzyline was investigated in four perfusion experiments at a glucose concentration of $150 \mathrm{mg} / 100 \mathrm{ml}$. Release of glucagon was not influenced while there was a slight stimulatory effect upon release of insulin, which increased to a mean percentage of 33\% (SEM \pm 4$)$. The mean results are condensed in Table IV.

Effect of propanolol and phentolamine upon epinephrine, norepinephrine, and isoproterenol influenced release during perfusion with a glucose concentration of 25 and $150 \mathrm{mg} / 100 \mathrm{ml}$ (type I experiments)

Propanolol. Simultaneous infusion of propanolol (1 $\mu \mathrm{M})$ with epinephrine, norepinephrine, and isoproterenol caused suppression or abolishment of the catechol induced glucagon release both at high and at low glucose concentrations. Following propanolol and epineph-

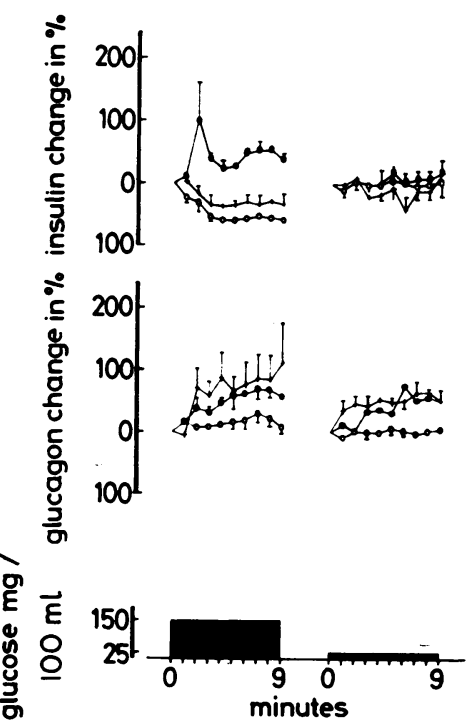

FIGLRE 2 Effect of norepinephrine. Mean percentage change of glucagon and insulin ( \pm SEM) during norepinephrine +-+ , norepinephrine and propanolol $\mathrm{O}-\mathrm{O}$, and norepinephrine and phentolamine infusion - - in the different perfusion experiments both at a glucose concentration of $150 \mathrm{mg} / 100 \mathrm{ml}$ (left) and at $25 \mathrm{mg} / 100 \mathrm{ml}$ (right). Table II gives the corresponding mean concentrations $( \pm$ SEM) from the same experiments and the number of stimulations. 
rine at a glucose concentration of $25 \mathrm{mg} / 100 \mathrm{ml}$ the mean glucagon level was $-2 \%(\mathrm{SEM} \pm 1, \mathrm{~N}=3)$ (Fig. 1); after propanolol and norepinephrine it was $3 \%(\mathrm{~N}=2)$ (Fig. 2) and after propanolol and isoproterenol it was $1 \%(\mathrm{~N}=2)$ (Fig. 3$)$. During perfusion with a glucose concentration of $150 \mathrm{mg} / 100 \mathrm{ml}$ propanolol also abolished or suppressed the catecholinduced glucagon release. After propanolol and epinephrine glucagon was $11 \%(\mathrm{SEM} \pm 6, \mathrm{~N}=4$ ) (Fig. 2). After propanolol and isoproterenol the glucagon release was completely abolished in three experiments and suppressed to a smaller extent in one experiment. The glucagon level during the infusion was $36 \%$ (SEM \pm 29 , $\mathrm{N}=4$ ). Excluding the experiment where the less pronounced suppression was obtained the mean percentage was $6 \%$ ( $\mathrm{SEM} \pm 8, \mathrm{~N}=3$ ) (Fig. 3).

Infusion of propanolol and epinephrine and propanolol and norepinephrine tended to accentuate the inhibition of insulin release induced by these substances alone at a glucose concentration of $150 \mathrm{mg} / 100 \mathrm{ml}$. Furthermore the transient stimulatory effect of epinephrine upon insulin release was completely abolished, the 2 min insulin value being $-4 \%$ (SEM \pm 6$)$. After propanolol and epinephrine insulin decreased to a mean level during the last $6 \mathrm{~min}$ of the infusion of $-68 \%$ ( $\mathrm{SEM} \pm 4, \mathrm{~N}=10$ ) (Fig. 1). After propanolol and norepinephrine it decreased to $-55 \%$ (SEM $\pm 4, \mathrm{~N}=$ 4) (Fig. 2). Infusion of propanolol and isoproterenol induced a smaller insulin release than that obtained after isoproterenol alone. However, propanolol was not able to abolish the response completely. Insulin rose to a peak at $2 \mathrm{~min}$ of $238 \%(\mathrm{~N}=2)$ and leveled off to a plateau at about the prestimulation value, namely $9 \%$ (Fig. 3). During perfusion with a glucose concentration of $25 \mathrm{mg} / 100 \mathrm{ml}$ propanolol and epinephrine caused a slight decrease in insulin to $-29 \%$ (SEM $\pm 9, N=3$ ) (Fig. 3) during the infusion. Propanolol and norepinephrine did not alter insulin release at this glucose concentration. Propanolol and isoproterenol completely abolished the increase in insulin seen after isoproterenol alone, insulin during the infusion being $3 \%(\mathrm{~N}=2)$ with no spike at 2 min (Fig. 3 ).

Phentolamine. Phentolamine $(1 \mu \mathrm{M})$ and epinephrine tended to cause an enhanced release of glucagon in comparison to the release seen after epinephrine alone. During perfusion with low glucose concentrations glucagon rose to $66 \%(\mathrm{~N}=2)$ (Fig. 1). Phentolamine caused no change in the glucagon release when infused together with norepinephrine in one experiment as compared with an infusion of norepinephrine alone. Glucagon rose to $42 \%$. Simultaneous infusion of phentolamine and isoproterenol also caused no further increase in glucagon compared to the increase seen after isoproterenol alone. It rose to $142 \%(\mathrm{~N}=2)$ (Fig. 3).

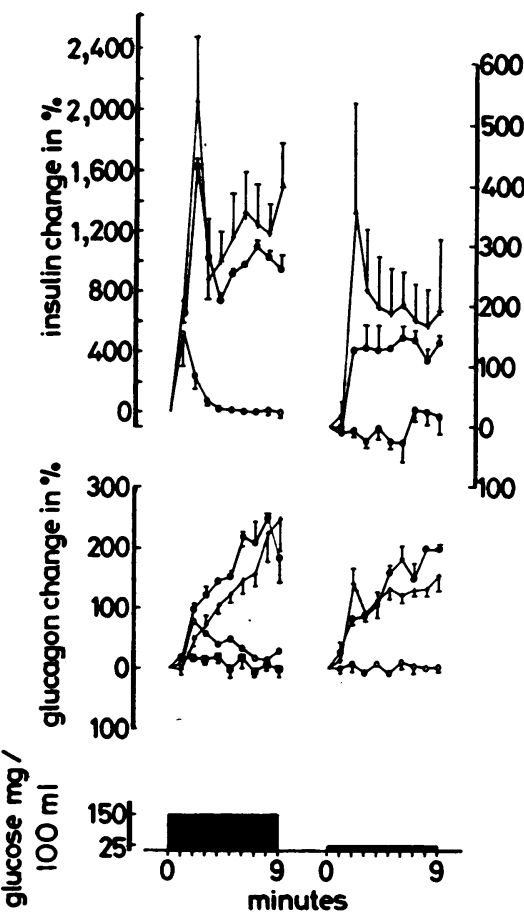

Figure 3 Effect of isoproterenol. Mean percentage change of glucagon and insulin $( \pm S E M)$ during isoproterenol +-+ , isoproterenol and propanolol $\mathrm{O}-\mathrm{O}(\mathrm{N}: 4)$, - $(N: 3)$, and isoproterenol and phentolamine infusion - in the different perfusion experiments both at a glucose concentration of $150 \mathrm{mg} / 100 \mathrm{ml}$ (left) and at $25 \mathrm{mg} / 100 \mathrm{ml}$ (right). Table III gives the corresponding mean concentrations ( $\pm S E M)$ from the same experiments and the number of stimulations.

During perfusion with high glucose concentrations phentolamine also appeared not to influence the catechol-induced glucagon release. After phentolamine and epinephrine glucagon rose to $94 \%(\mathrm{SEM} \pm 29, \mathrm{~N}=5)$ (Fig. 1), after phentolamine and norepinephrine it rose to $50 \%(\mathrm{~N}=2)$ (Fig. 2) and after phentolamine and isoproterenol the value was $170 \%(\mathrm{~N}=2)$ (Fig. 3 ).

At a glucose concentration of $150 \mathrm{mg} / 100 \mathrm{ml}$ infusion of phentolamine together with epinephrine or norepinephrine reversed the inhibition of insulin release obtained with these substances alone. The insulin release now followed a biphasic release pattern as described following isoproterenol. After phentolamine and epinephrine insulin rose to $777 \%(\mathrm{SEM} \pm 197, \mathrm{~N}=5)$ at 2 min and leveled off at a plateau of $420 \%($ SEM \pm 84$)$ (Fig. 1). After phentolamine and norepinephrine it increased to $100 \%(\mathrm{~N}=2)$ at $2 \mathrm{~min}$ followed by a plateau of $41 \%$ (Fig. 2). The addition of phentolamine to an isoproterenol infusion induced no change in insulin release. The same biphasic pattern was obtained as after isoproterenol alone. Insulin rose to $1,615 \%(\mathrm{~N}$ $=2$ ) and leveled off at a plateau of $1,039 \%$ (Fig. 3). 
At the low glucose concentration alpha receptor blockade abolished the slight decrease in insulin seen after epinephrine alone and did not affect the response seen after norepinephrine. After isoproterenol in two experiments there was an increase to $136 \%$ during the infusion (Fig. 3). The $2 \mathrm{~min}$ value was not different from the mean value during the entire infusion.

Effect of dibenzyline upon epinephrineinfluenced release and effect of propanolol upon isoproterenol- and epinephrine-influenced release during perfusion with a glucose concentration of $150 \mathrm{mg} / 100 \mathrm{ml}$ (type II experiments )

Dibenzyline. As the presence of alpha receptors on glucagon producing cells in the pancreas could not be clearly demonstrated using the alpha blocking compound phentolamine, it was decided to try another alpha blocker, dibenzyline, which, having slightly different pharmacological characteristics, might have advantages over phentolamine. Furthermore the effect of only one catecholamine was investigated in each experiment to avoid possible errors that might be inherent in the experimental situations where several agents were tested in the same perfusion experiment.

The glucagon response to a $15 \mathrm{~min}$ infusion of epinephrine was compared to a $15 \mathrm{~min}$ infusion of epinephrine and dibenzyline, which was preceded by a 10 min infusion of dibenzyline alone. Three such experiments were performed at $150 \mathrm{mg} / 100 \mathrm{ml}$ glucose. Using this experimental design, dibenzyline in one experiment enhanced the catechol-induced glucagon release (Fig. 4); in two other experiments a slight suppression was seen. The effect of dibenzyline upon the catecholinfluenced insulin release was unambiguous: it caused a reversal of the epinephrine-induced inhibition to a stimulation.

In another series of four experiments dibenzyline was infused 10-15 min after start of the epinephrine infusion in order to study whether an alpha receptor blockade during catechol-induced glucagon release would change the pattern of release. Again no consistent change in glucagon release was observed. In two experiments there was a slight though insignificant enhancement of the glucagon release (Fig. 5); in two other experiments no effect was obtained (Fig. 6). The effect upon insulin release again was a reversal of an inhibition to a stimulation. Mean results of these experiments are recorded in Table V.

Propanolol. Propanolol was investigated using the same experimental design. When propanolol was infused 10-15 min after start of isoproterenol infusion glucagon release was greatly suppressed and insulin release was inhibited. Four such perfusion experiments were carried out and comparable results were obtained (Table
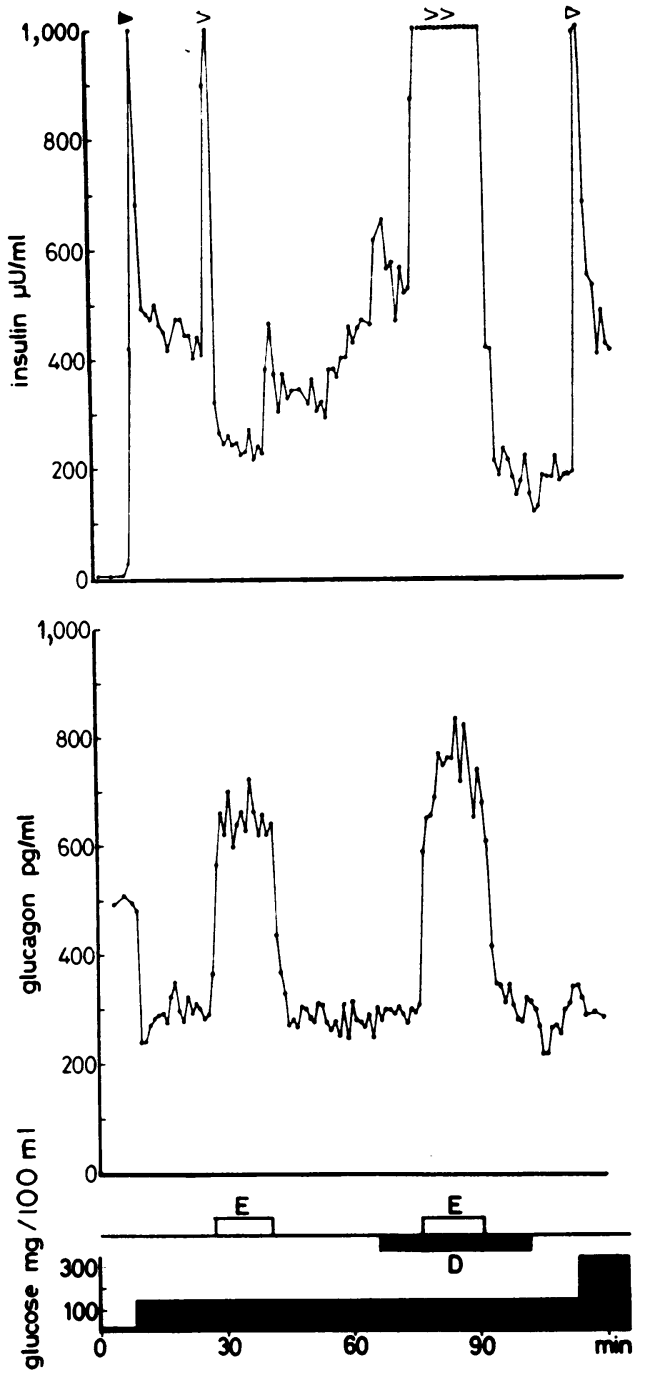

FIGURE 4 Effect of dibenzyline upon epinephrine-induced changes in the secretion of pancreatic glucagon and insulin during perfusion with a glucose concentration of $150 \mathrm{mg} /$ $100 \mathrm{ml}$. $>$ peak value $1,081 \mu \mathrm{U} / \mathrm{ml}, \triangleright$ peak value 1,038 $\mu \mathrm{U} / \mathrm{ml} .>$, $>>$, see Table $\mathrm{V}$ experiment no. 1 , lower panel. $\mathrm{E}$, epinephrine; $\mathrm{D}$, dibenzyline.

VI and Fig. 7). In one experiment (Fig. 8) propanolol was infused $10 \mathrm{~min}$ after start of an epinephrine infusion. Again glucagon was suppressed and insulin release further inhibited. The figure also shows an identical biphasic glucagon response to arginine before and after the blocker infusion proving intact responsiveness of the alpha cells during the experimental period.

\section{DISCUSSION}

In the present investigation results are reported on the effect of adrenergic substances on the secretion of pancreatic glucagon and insulin. The study has shown 
that epinephrine, norepinephrine, and isoproterenol stimulate secretion of glucagon. Furthermore the stimulatory effect of these substances has been characterized to be mediated through beta receptors. New observations and confirmatory evidence on the effect of adrenergic substances on the secretion of insulin has also been presented.

In vivo studies on the effect of adrenergic substances on the secretion of glucagon have not been reported. The results from studies on the isolated incubated pancreatic tissue have been contradictory. Vance, $\mathrm{Bu}$ chanan, and Williams (15) thus found that none of the substances in question affected release of glucagon
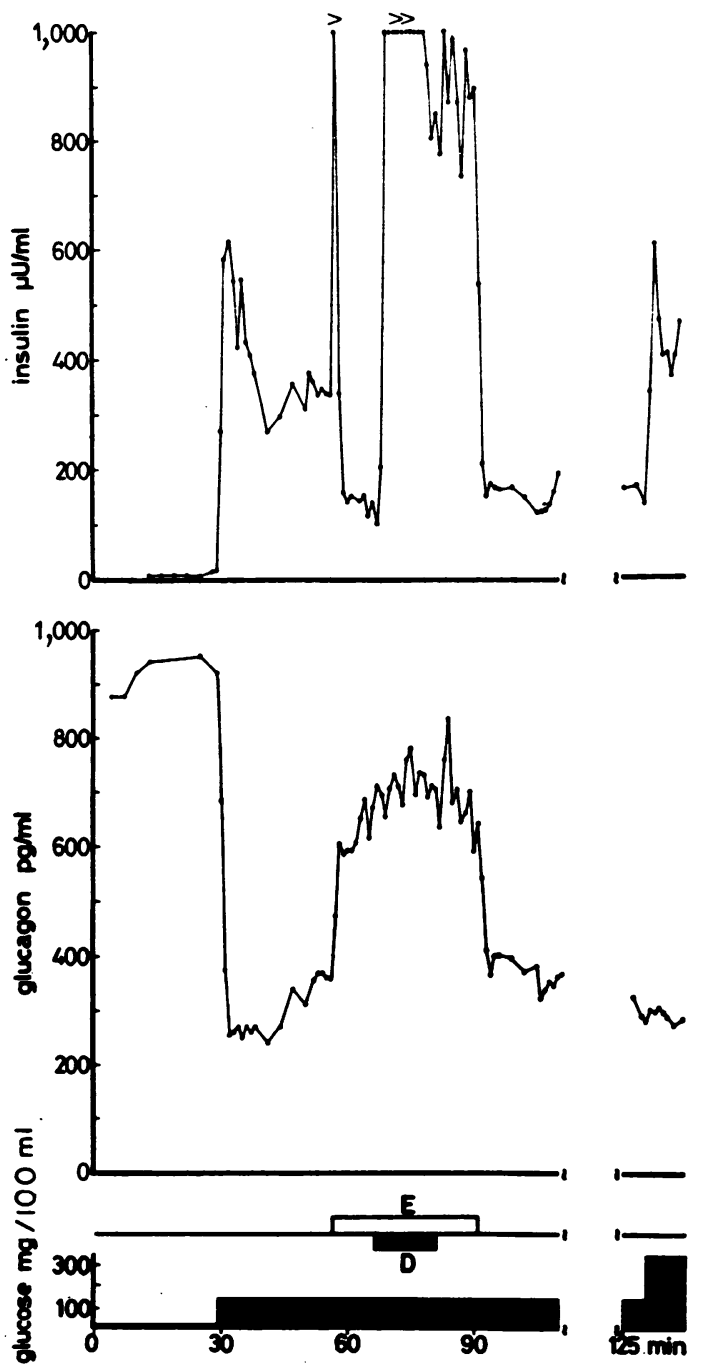

Figure 5 Effect of dibenzyline upon epinephrine-induced changes in the secretion of pancreatic glucagon and insulin during perfusion with a glucose concentration of $150 \mathrm{mg} /$ $100 \mathrm{ml} .>,>>$, see Table $\mathrm{V}$ experiment no. 1, upper panel. E, epinephrine; $D$, dibenzyline.
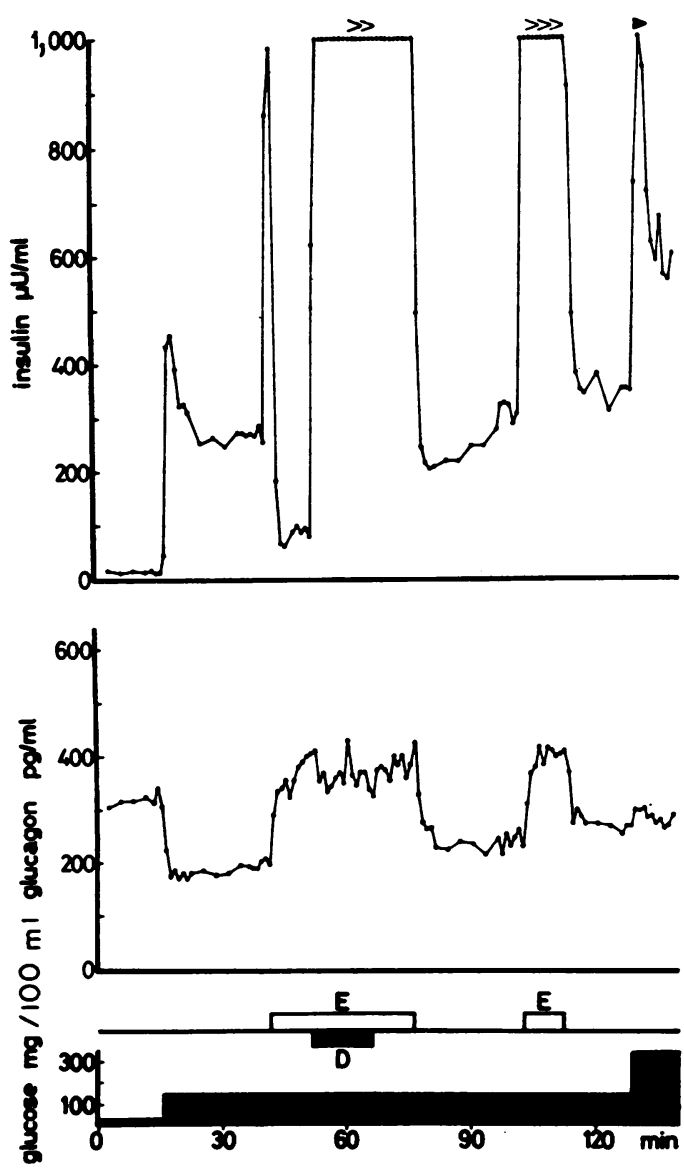

FigLre 6 Effect of dibenzyline upon epinephrine-induced changes in the secretion of pancreatic glucagon and insulin during perfusion with a glucose concentration of $150 \mathrm{mg} /$ $100 \mathrm{ml} .>>$, see Table V experiment no. $2,>>>4,396$, $2,215,1,878,2,099,2,644,2,230,2,450,2,279,2,181,1,879$, 1,013. E, epinephrine; $\mathrm{D}$, dibenzyline.

in the isolated islet system while Leclercq-Meyer, Brisson, and Malaisse (16) briefly reported that epinephrine had a stimulatory effect upon glucagon release in pancreatic slices obtained after atrophy of the exocrine tissue by duct ligature.

In the present in vitro study epinephrine and norepinephrine in concentrations as low as $2 \mathrm{ng} / \mathrm{ml}$-i.e., within the levels occurring during exercise, stress, and hypoglycemia-stimulated release of glucagon during perfusion with a glucose concentration of $150 \mathrm{mg} / 100$ $\mathrm{ml}$ which in itself blocks the basal glucagon release. A significant effect was also obtained with catecholamine concentrations as low as $0.5 \mathrm{ng} / \mathrm{ml}$ (results not shown).

The catechols investigated all stimulated glucagon in a monophasic response pattern different from the characteristic biphasic release of glucagon following infusions of pancreozymin, gastrin, and arginine pre- 
TABLE V

Effect of Dibenzyline on Epinephrine-Induced Changes in the Secretion of $P G^{*}$ and I $\ddagger$ during Perfusion with a Glucose Concentration of $150 \mathrm{mg} / 100 \mathrm{ml}$

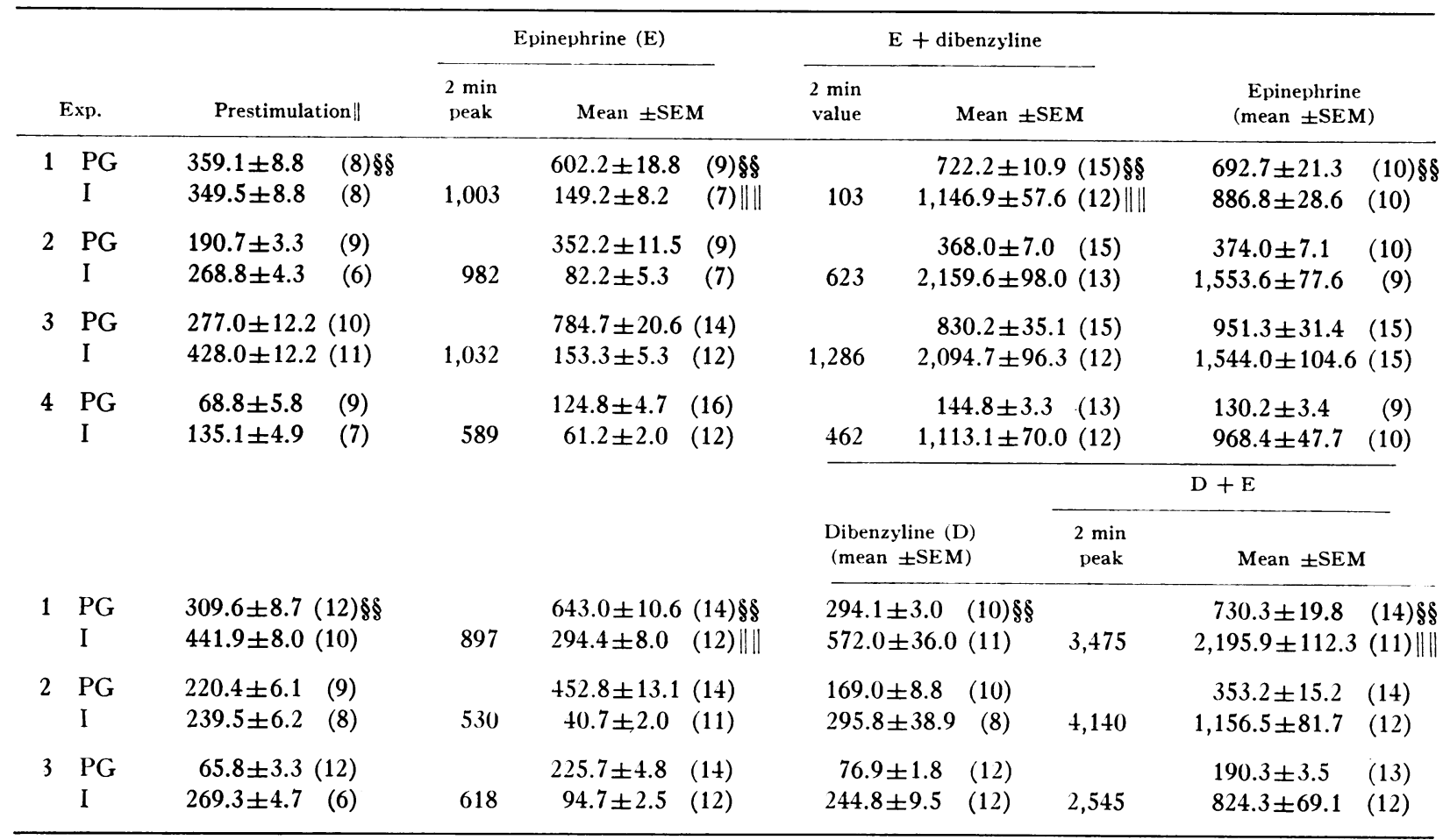

See footnotes Table I and:

$\$$ Number of samples obtained during the prestimulation period and during infusion of epinephrine, epinephrine and dibenzyline, and epinephrine.

III The mean insulin concentration $( \pm$ SEM) during the infusion minus the first three samples.

viously reported from our laboratory (11). An attractive explanation for this difference in response could be that the adrenergic stimulation of the alpha cells influenced alpha and beta receptors to a varying degree, the response observed, being a net result of stimulatory and inhibitory effects upon the release and not a one-

TABLE VI Effect of Propanolol on Isoproterenol-Induced Stimulation on the Secretion of

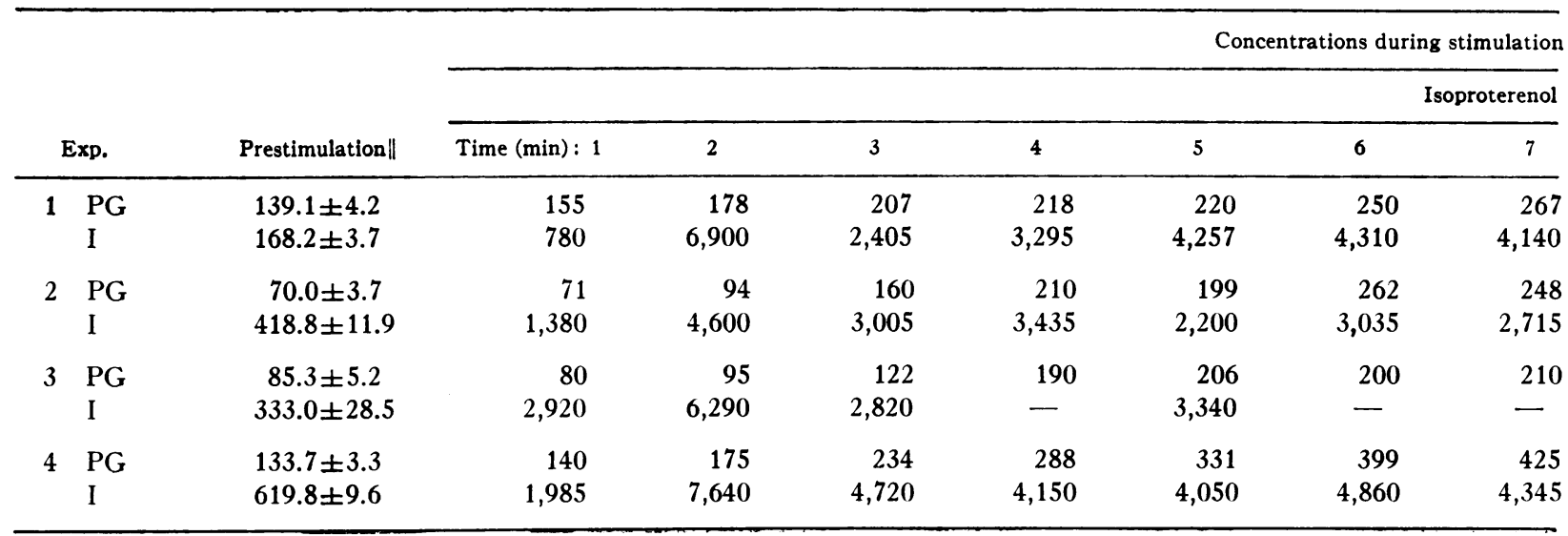

See footnotes Table I. 
way stimulatory effect as exerted by gastrointestinal hormones and amino acids (however, see later).

The beta receptor stimulant (17), isoproterenol, was a potent releaser of glucagon. Furthermore our finding that isoproterenol-induced glucagon release was suppressed or completely abolished by simultaneous infusion of the specific beta receptor blocking compound, propanolol, has clearly demonstrated that the mechanism responsible for glucagon release following adrenergic substances was via a beta receptor.

On the basis of preliminary experiments we reported results that indicated that epinephrine induced a slightly higher glucagon release during alpha receptor blockade than the release attained after epinephrine alone (18). Closer analysis, however, revealed that this augmented release was insignificant. Epinephrine also did not suppress glucagon release below the preinfusion level during simultaneous infusion of propanolol. These two findings might indicate that no alpha receptors were present on the alpha cells of the islets of Langerhans or so few that they might be considered to have no importance. However, the negative results could also be due to pitfalls in the experimental design: (a) The presence of a catecholamine during the development of blockade by a halyalkylamine might cause a competition between the two drugs for the same population of receptors $(19,20)$. (b) The concentration of the blocking compounds used might be insufficient to produce a total receptor blockade on the alpha cell even if it appeared to be effective on the beta cell. (c) A catecholamine infusion might influence the functional state of the alpha cells in such a way that a later simultaneous catecholamine-alpha-blocker infusion would not be able to produce a higher increment. (d) The fact that several agents were often tested in the same perfusion experiment (type I experiments) might influence the responses obtained.

We tried to avoid these possible pitfalls, using another design and using high doses of dibenzyline, another alpha receptor blocking compound, which is more readily bound to the tissue and more potent. In one experimental series dibenzyline was infused $10 \mathrm{~min}$ prior to the catecholamine infusion to ensure saturation of the alpha receptors before introducing epinephrine into the system. In another series of experiments dibenzyline was given $10 \mathrm{~min}$ after start of the catecholamine infusion during the first hour of the perfusion period to make it less likely that a lack of effect was due to an altered functional activity of the alpha cell or to an exhausted alpha cell population. In both instances alpha-blockade by dibenzyline did not consistently enhance epinephrine induced glucagon release, while release of insulin was influenced as expected, exhibiting a stimulation instead of an inhibition. When the betaadrenergic blocking agent propanolol was investigated using the same experimental design (type II experiments) isoproterenol- and epinephrine-induced glucagon release was greatly suppressed and insulin release suppressed or further inhibited. The fact that a nonadrenergic substance like the amino acid arginine at physiological concentrations releases glucagon to the same degree before and after a catecholamine and blocker infusion speaks for an intact responsiveness of the alpha cell. Thus on the basis of the present experimental preparation and set-up, we may conclude that no evidence could be obtained supporting the presence of alpha receptors on the alpha cells of the islets of Langerhans.

Epinephrine and norepinephrine inhibited secretion of insulin, while isoproterenol was a strong stimulus for

$P G^{*}$ and I during Perfusion with a Glucose Concentration of $150 \mathrm{mg} / 100 \mathrm{ml}$

\begin{tabular}{|c|c|c|c|c|c|c|c|c|c|c|c|c|}
\hline \multirow[b]{2}{*}{8} & \multirow[b]{2}{*}{9} & \multirow[b]{2}{*}{10} & \multicolumn{10}{|c|}{ Isoproterenol and propanolol } \\
\hline & & & 11 & 12 & 13 & 14 & 15 & 16 & 17 & 18 & 19 & 20 \\
\hline 302 & 325 & 290 & 301 & 265 & 227 & 198 & 198 & 193 & 174 & 157 & 175 & 122 \\
\hline 3,195 & 3,680 & 2,590 & 1,835 & 1,000 & 415 & 272 & 240 & 204 & 194 & 190 & 164 & 188 \\
\hline 242 & 240 & 230 & 227 & 140 & 126 & 127 & 107 & 108 & 102 & 120 & 98 & 90 \\
\hline 2,820 & 3,070 & 2,080 & 3,050 & 1,320 & 525 & 343 & 286 & 270 & 281 & 301 & 270 & 227 \\
\hline 230 & 227 & 247 & 250 & 215 & 117 & 90 & 92 & 100 & 72 & 62 & 50 & 38 \\
\hline 3,025 & 2,850 & 3,350 & 3,440 & 1,855 & 680 & 256 & 213 & 168 & 186 & 162 & 157 & 156 \\
\hline 510 & 487 & 473 & 502 & 446 & 280 & 235 & 187 & 160 & 169 & 185 & 190 & 159 \\
\hline 3,300 & 2,625 & - & - & 2,555 & 1,010 & 530 & 426 & 370 & 370 & 318 & 318 & 348 \\
\hline
\end{tabular}



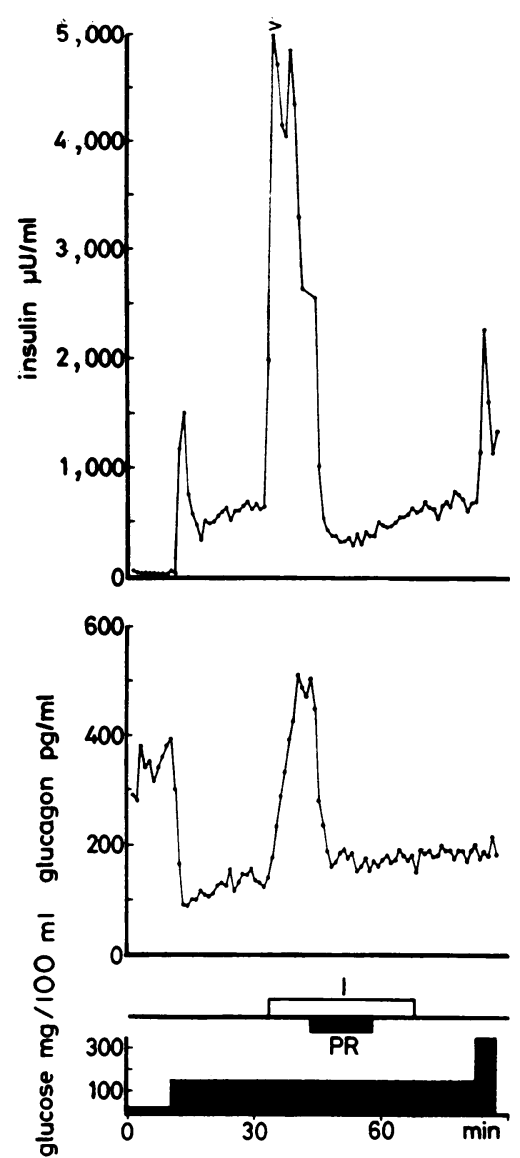

FigUre 7 Effect of propanolol upon isoproterenol-stimulated secretion of pancreatic glucagon and insulin during perfusion with a glucose concentration of $150 \mathrm{mg} / 100 \mathrm{ml}$. $>$, see Table VI experiment no. 4. PR, propanolol.

insulin release. Using specific receptor blocking compounds we found that the effect of catechols on insulin release was consistent with an alpha receptor effect (Fig. 9). Our results are thus consistent with most in vitro and in vivo data concerning the effect of catechols on insulin release. Our demonstration that epinephrine has a short transient stimulatory effect upon insulin release before inhibition takes place, and that this effect is completely abolished during beta blockade has not been described previously.

It is interesting that the insulin responses to epinephrine and norepinephrine during simultaneous alpha blockade of the organ always followed a biphasic release pattern similar to that seen after glucose, gastrointestinal hormones, amino acids, tolbutamide, and the beta receptor stimulant isoproterenol. This might lead us to suggest that the effect of these physiological stimuli could be mediated through a receptor of a more broad specificity, characterized by affecting release of insulin in a biphasic pattern. Further support for this theory is the recent in vivo observation that propanolol suppresses tolbutamide-induced insulin release (21).

In this connection it may also be of interest that our results have shown that isoproterenol releases insulin at a glucose concentration normally found insufficient for many insulin releasing stimuli. Isoproterenol, in this respect, thus appears to resemble substances like tolbutamide and leucine. Whether this means that isoproterenol, tolbutamide, and leucine share a common receptor, or fit better into one part of a receptor which enables them to release insulin, is only speculative at the moment.

The results obtained from infusions of catecholamines
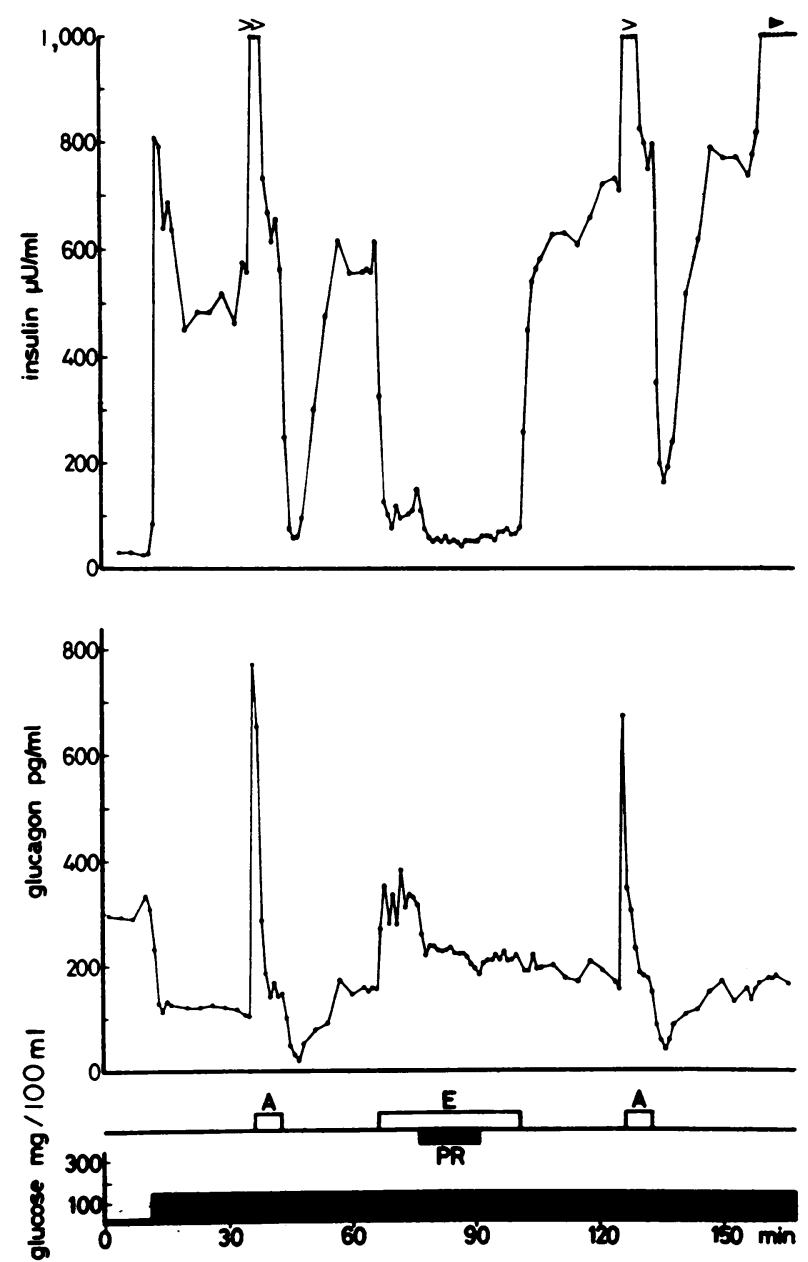

FigURE 8 Effect of propanolol upon epinephrine-induced changes in the secretion of pancreatic glucagon and insulin during perfusion with a glucose concentration of 150 $\mathrm{mg} / 100 \mathrm{ml}$. In addition: effect of arginine on the secretion of pancreatic glucagon and insulin before and after the epinephrine-propanolol infusion. $>>1,899,4,123,1,478 \mu \mathrm{U} /$ $\mathrm{ml},>1,164,4,162,1,858,1,293 \mu \mathrm{U} / \mathrm{ml}, \longrightarrow 2,020,2,470$, $2,117,2,360,1,690,1,706,1,678,1,825,1,658 \mu \mathrm{U} / \mathrm{ml}$. PR, propanolol; E, epinephrine; A, arginine. 


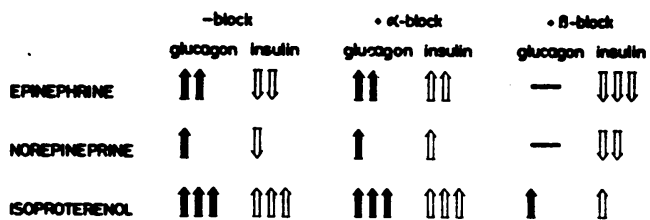

Figure 9 Effect of catechols on glucagon and insulin release using specific receptor blocking compounds.

in vivo in man and from most in vitro studies have shown that an effect on insulin release was only observed with high concentrations of epinephrine and norepinephrine, promoting the idea that any effect of catecholamines in vivo would be due to release of catecholamines, especially norepinephrine, locally from the sympathetic nerve endings in the islets. However, the finding in this investigation of an effect of concentrations of catecholamines in the physiological range suggest that minor changes in the circulating level of catechols may exert a direct effect upon the hormone response from the islets of Langerhans, although sympathetic discharge from the nerve endings in the islets also could be an important adrenergic mechanism for modulating the response of the islet cells to other humoral stimuli and inhibitors. Perfusion flow and perfusion pressure were completely constant during the experimental period and surprisingly were not influenced by the infusion of catechols in the concentrations used.

In the present communication evidence has been presented that the alpha cells and the beta cells are under the influence of changes in the catecholamine concentration in the perfusing medium. Furthermore the receptor for the catecholamine-induced effect has been characterized, stimulation of the release of both hormones being mediated through beta receptors. The effect of adrenergic substances in the intact unblocked pancreas, however, is an enhanced glucagon release and a decreased insulin release. The reason for these responses is that the alpha cells have beta receptors and none, or very few alpha receptors, while the beta cells have an adequate number of alpha receptors. As the presence of these receptors have been unambiguously demonstrated, it seems of importance to try to establish the physiological significance in further experiments.

It has been suggested by Porte (22) that the catecholamine release which is stimulated by infection, stress, and volume depletion may be an important factor in some patients with diabetic ketoacidosis increasing glycogenolysis and lipolysis and inhibiting insulin release. It would appear from the foregoing that pancreatic glucagon secreted in response to increased catechol levels would fit in with this theory and contribute to a worsening of the situation by augmenting glycogenolysis and gluconeogenesis in the liver.
Bottger, Faloona, and Unger reported a rise in pancreatic glucagon after heavy exercise in fasting dogs (23). As plasma catecholamines measured with a highly sensitive double isotope technique have been found to increase to levels above the concentrations used in the present study after heavy exercise in man (24), we should like to suggest that the rise in plasma catecholamines could be responsible for the rise in glucagon.

\section{ACKNOWLEDGMENTS}

I am very grateful to Mrs. Karen Just for most conscientious and skillful technical assistance.

This study was supported by grants from Statens lægevidenskabelige Forskningsraad, King Chr. Xth Fund and a NOVO research grant.

\section{REFERENCES}

1. Porte, D., Jr., A. L. Graber, T. Kuzuya, and R. H. Williams. 1966. The effect of epinephrine on immunoreactive insulin levels in man. J. Clin. Invest. 45: 228.

2. Porte, D., Jr., and R. H. Williams. 1966. Inhibition of insulin release by norepinephrine in man. Science (Wash. D.C.). $152: 228$.

3. Coore, H. G., and P. J. Randle. 1964. Regulation of insulin secretion with pieces of rabbit pancreas incubated in vitro. Biochem. J. 93: 66.

4. Malaisse, W., F. Malaisse-Lagae, P. H. Wright, and J. Ashmore. 1967. Effects of adrenergic and cholinergic agents upon insulin secretion in vitro. Endocrinology. 80: 975.

5. Loubatieres, A., M. M. Mariani, and J. Chapal. 1970. Insulino-sécrétion étudiée sur le pancréas isolé et perfusé du rat. II. Action des catécholamines et des substances bloquant les récepteurs adrénergique. Diabetologia. 6: 533 .

6. Porte, D., Jr. 1967. A receptor mechanism for the inhibition of insulin release by epinephrine in man. $J$. Clin. Invest. 46: 86.

7. Porte, D., Jr. 1967. Beta adrenergic stimulation of insulin release in man. Diabetes. $16: 150$.

8. Iversen, J., and D. W. Miles. 1971. Evidence for a feedback inhibition of insulin on insulin secretion in the isolated, perfused canine pancreas. Diabetes. 20: 1.

9. Ørskov, H. 1967. Wich-chromatography for the immunoassay of insulin. Scand. J. Clin. Lab. Invest. 20: 297.

10. Ørskov, H., H. Yde, and H. G. Thomsen. 1968. Wick chromatography for rapid and reliable immunoassay of insulin, glucagon and growth hormone. Nature (Lond.). 219: 193 .

11. Iversen, J. 1971. Secretion of glucagon from the isolated perfusion canine pancreas. J. Clin. Invest. 50: 2123.

12. Unger, R. H., H. Ketterer, J. Dupré, A. M. Eisentraut, and J. Exton. 1968. Characterization of the responses of circulating glucagon-like immunoreactivity to intraduodenal and intravenous administration of glucose. J. Clin. Invest. $47: 48$.

13. Moody, A. J., F. Markussen, F. Sundby, A. Steenstrup, and A. Schaich Fries. 1970. The insulin releasing activities of extracts of pork intestine. Diabetologia. 6: 135. 
14. Kaneto, A., Y. Mizuno, Y. Tasaka, and K. Kosaka. 1970. Stimulation of glucagon secretion by tetragastrin. Endocrinology. 86: 1175.

15. Vance, J. E., K. D. Buchanan, and R. H. Williams. 1971. Glucagon and insulin release: Influence of drugs affecting the autonomic nervous system. Diabetes. 20: 78.

16. Leclercq-Meyer, V., G. R. Brisson, and W. J. Malaisse. 1971. Effect of adrenalin and glucose on release of glucagon and insulin in vitro. Nat. New Biol. 231: 248.

17. Ahlquist, R. P. 1948. A study of the adrenotropic receptors. Am. J. Physiol. 153 : 586.

18. Iversen, J. 1971. Adrenergic receptors for the secretion of immunoreactive glucagon and insulin from the isolated perfused canine pancreas. Diabetologia. 7: 485. (Abstr.)

19. Nickerson, M., and W. S. Gump. 1949. The chemical basis for adrenergic blocking activity in compound related to dibenamine. J. Pharmacol. Exp. Ther. 97: 25.

20. Nickerson, M. 1956. Receptor occupancy and tissue response. Nature (Lond.). 178: 697.

21. Massara, F., E. Strumia, F. Carnanni, and G. M. Molinatti. 1971. Depressed tolbutamide-induced insulin response in subjects treated with propanolol. Diabetologia. $7: 287$.

22. Porte, D., Jr. 1969. Sympathetic regulation of insulin secretion: Its relation to diabetes mellitus. Arch. Intern. Med. 123: 252.

23. Bottger, I., G. R. Faloona, and R. H. Unger. 1971. The effect of intensive physical exercise on pancreatic glucagon. Diabctes. 20 (Suppl. 1) : 339.

24. Christensen, N. J. 1970. Abnormally high plasma catecholamines at rest and during exercise in ketotic juvenile diabetics. Scand. J. Clin. Lab. Invest. 26: 343. 